\title{
First record of Aglae caerulea (Hymenoptera, Apidae, Euglossini) in Brazilian Cerrado east of the Amazon Region, Maranhão State, Brazil
}

\author{
D. C. Martins ${ }^{a *}$, P. M. C. Albuquerque ${ }^{b}$, F. S. Silva ${ }^{c}$ and J. M. M. Rebêlod \\ aPrograma de Pós-graduação em Biodiversidade e Conservação, Universidade Federal do Maranhão - UFMA, \\ Av. dos Portugueses, 1966, Cidade Universitária, CEP 65080-805, São Luís, MA, Brazil

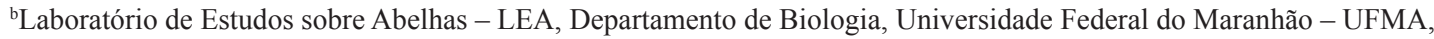 \\ Av. dos Portugueses, 1966, Cidade Universitária, CEP 65080-805, São Luís, MA, Brazil \\ ${ }^{\circ}$ Centro de Ciências Agrárias e Ambientais, Universidade Federal do Maranhão - UFMA, Campus IV, \\ Rodovia MA 230, s/n, Boa Vista, CEP 65500-000, Chapadinha, MA, Brazil \\ ${ }^{\text {d} L a b o r a t o ́ r i o ~ d e ~ E n t o m o l o g i a ~ d e ~ V e t o r e s ~-~ L E V, ~ D e p a r t a m e n t o ~ d e ~ P a t o l o g i a, ~ U n i v e r s i d a d e ~ F e d e r a l ~ d o ~ M a r a n h a ̃ o ~-~ U F M A, ~}$ \\ Praça Madre Deus, 02, CEP 65025-560, São Luís, MA, Brazil \\ *e-mail: martinsdc.bio@gmail.com
}

Received: April 24, 2015 - Accepted: September 3, 2015 - Distributed: May 31, 2016

(With 2 figures)

\section{Introduction}

Aglae caerulea Lepeletier \& Serville, a monospecific genus of Euglossini is characterized by its small body size (20 to $28 \mathrm{~mm}$ ) and blue color (Dressler, 1982). Females of this species are cleptoparasites of Eufriesea and Eulaema nests (Moure, 1964). The males are rarely found in flowers or in other natural sources of aromatic substances, or even in baited traps. For this reason, they are underrepresented in entomological collections (Morato, 2001). A. caerulae males attracted to aromatic substances under natural conditions (as is characteristic of Euglossini bees) were first observed recently in inflorescences of Anthurium rubrinervium (Link) G. Don (Araceae) in an area of tropical forest in French Guiana (Hentrich et al., 2007). Moreover, three specimens of this species had been attracted and collected using methyl cinnamate baits in Dawa, British Guiana (Williams and Dodson, 1972).

Until recently, A. caerulea was considered endemic to the Amazon region (Cameron, 2004), and was found in the Amazon rainforest of Brazil, Colombia, French Guiana, and Guyana (Ramirez et al., 2002). In Brazil, records indicate the presence of $A$. caerulea in the states of Acre, Amazonas, Amapá, and Pará (Silveira et al., 2002). Recently, its presence was recorded in phytophysiognomic studies of gallery forests within areas of Cerrado in Mato Grosso State, Brazil, where males were attracted and captured in methyl cinnamate baited traps (Anjos-Silva et al., 2006; Silva et al., 2013). Although several entomological surveys have used a variety of chemical baits (Rebêlo and Silva, 1999; Albuquerque et al., 2001; Brito and Rêgo, 2001; Silva and Rêbelo, 2002, Carvalho et al., 2006; Mendes et al., 2008; Silva et al., 2009; Silva, 2012), A. caerulea was not previously found in any of the areas studied in Maranhão State. The absence of this species, especially in rainforests, is most likely because methyl cinnamate baits, for which A. caerulea has an affinity, were not used. This was also observed by Morato (2001) in studies performed in the Parque Nacional da Serra do Divisor in Acre State, and by Anjos-Silva et al. (2006) in a gallery forest in the Chapada dos Guimarães Brazilian National Park in Mato Grosso State. The main goal of the present study was to check if Aglae caerulea occurs in the Cerrado domain east of the Amazon Region.

\section{Material and Methods}

The study was conducted in a gallery forest in the savannah of the Parque Estadual do Mirador within the limits of the municipality of Formosa da Serra Negra (6 37 ' 56.29” S; 45 53' 4.25” W), Maranhão State, Brazil. It is Maranhão State's largest conservation unit and is located between the sources of the Alpercatas and Itapecuru rivers ( $6^{\circ} 37^{\prime} 30.15^{\prime}$ ' S; 45 $45^{\circ}$ ' $30.70^{\prime}$ ' $\mathrm{W}$, respectively), occupying approximately 450 ha within the south central region of the state. The park extends through portions of Mirador, Grajaú, São Raimundo das Mangabeiras, and Formosa da Serra Negra (Conceição and Rodrigues, 2010). The climate is sub-humid, with an annual rainfall of $1,200 \mathrm{~mm}$. The mean maximum temperature ranges from $31.4^{\circ} \mathrm{C}$ to $33^{\circ} \mathrm{C}$ and the mean minimum temperature ranges from $19.5^{\circ} \mathrm{C}$ to $21^{\circ} \mathrm{C}$ (Conceição et al., 2011).

The sampling was done between January 2012 and December 2013. Five aromatic compounds were used to attract the male euglossine bees: methyl cinnamate, eucalyptol, eugenol, methyl salicylate, and vanillin (modified from Campos et al., 1989). For each aromatic compound, we used three baits that were exposed for 10 consecutive hours (from 7 to $17 \mathrm{~h}$ ). In total, 15 baits were installed 8 meters apart from each other along the riverbank. The captured specimens were deposited in the bee collection of the Laboratory of Bee Studies of the Biology Department of the Federal University of Maranhão, Brazil.

\section{Results and Discussion}

In this study, two A. caerulea males (Figure 1) were obtained in August 2013 and November 2013 during a survey performed in a gallery forest. The area where the 
male $A$. caerulea specimens were found is part of a polygon of possible occurrence, which extends throughout the gallery forests in Pará, Amazonas, Mato Grosso (northern region), and Tocantins states, according to Silva et al. (2013) (Figure 2).
The occurrence of species from the Amazon region in other nearby ecosystems is most likely due to the presence of closed areas such as gallery forests, coconut forests, and sandbanks, which comprise denser vegetation and
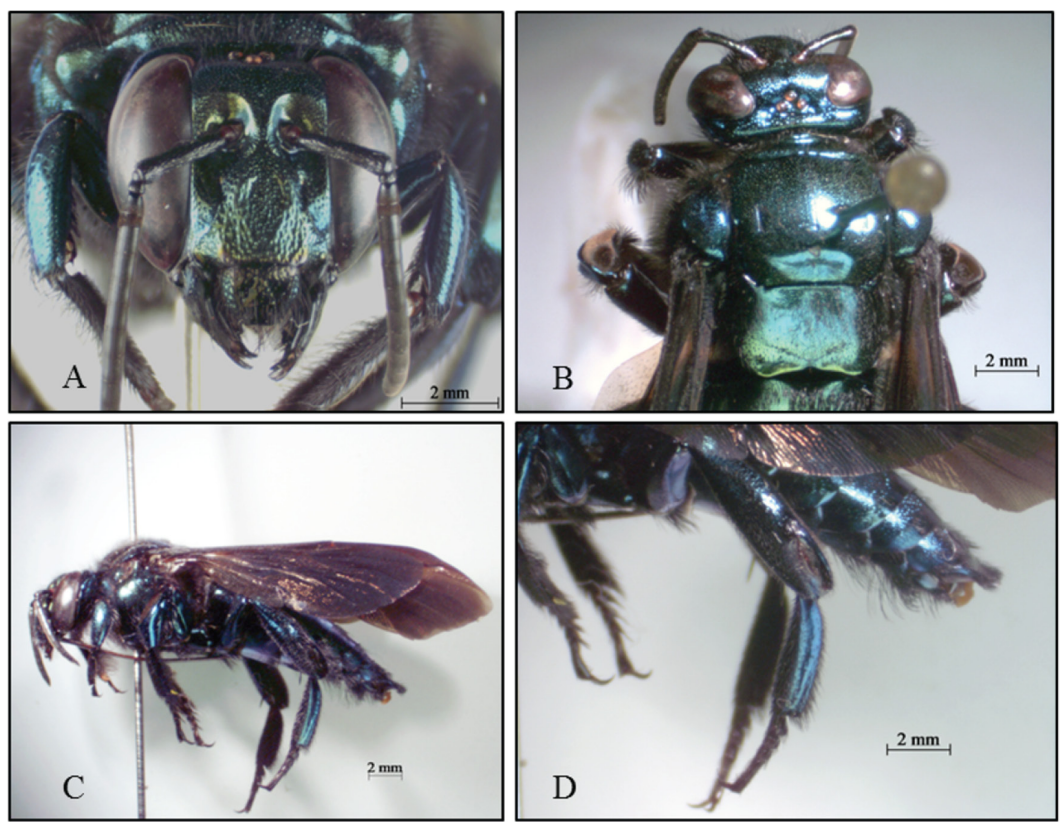

Figure 1. Aglae caerulea male collected using methyl cinnamate baited traps: (A) anterior view, slightly greenish clypeus; (B) dorsal view, showing the flat scutellum; (C) lateral view, mesosome; (D) very elongated and straight hind tibia, with tibial groove in terminal position.

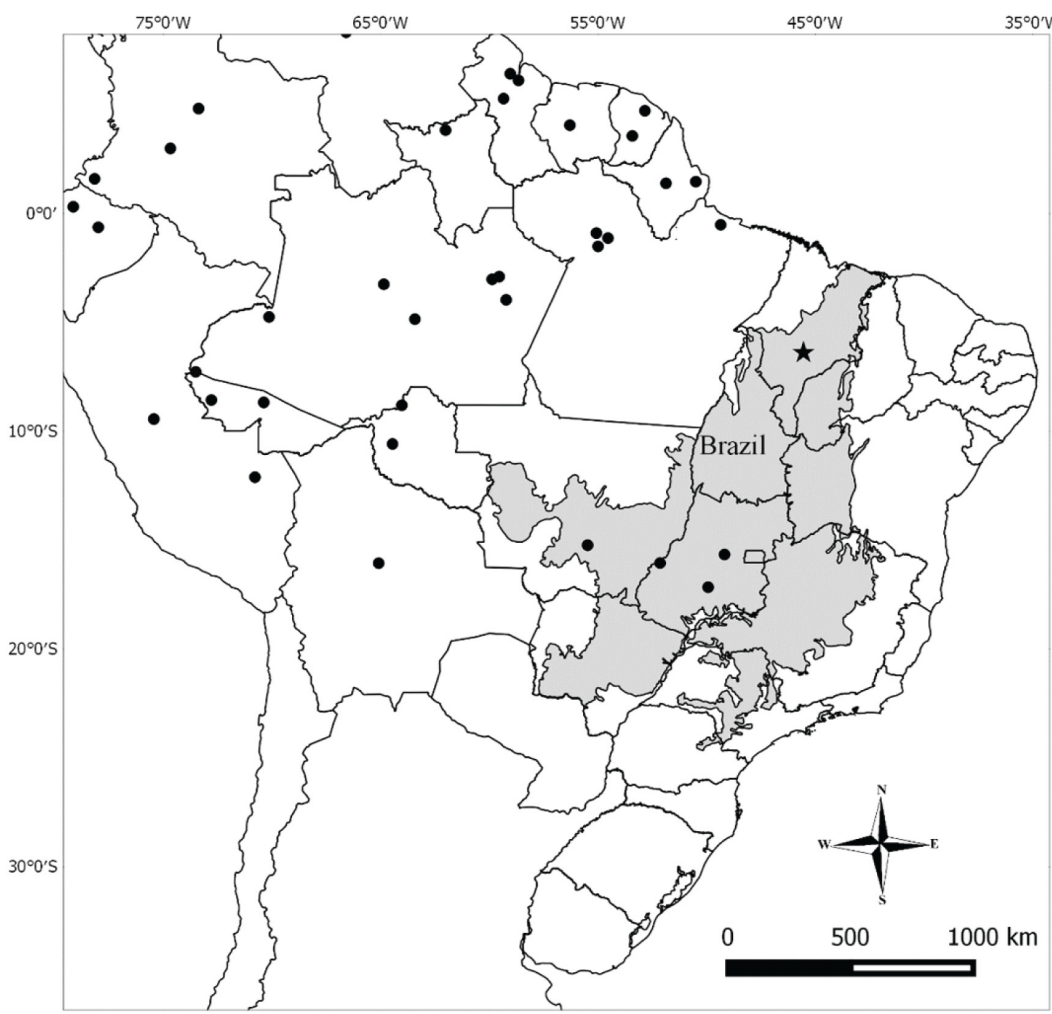

Figure 2. Map showing the Brazilian Cerrado (grey area) and known geographic distribution of Aglae caerulea (black circles) according to Silva et al. (2013), with highlight for the new record found in the Maranhão state (star). 
thus favor the dispersal of Euglossini species, which are considered common in forest environments (Dressler, 1982). The results obtained by Moura and Schlindwein (2009) in studies on riparian forests of the São Francisco River corroborate this hypothesis, highlighting that these environments are used as wildlife corridors, harboring and maintaining Euglossini species that are only common in tropical rainforests.

\section{References}

ALBUQUERQUE, P.M.C., FERREIRA, R.G., RÊGO, M.M.C., SANTOS, C.S. and BRITO, C.M.S., 2001. Levantamento da fauna de abelhas silvestres (Hymenoptera, Apoidea) na região da Baixada Maranhense: Vitória do Mearim, MA, Brasil. Acta Amazonica, vol. 31, no. 3, pp. 419-430. http://dx.doi.org/10.1590/180943922001313430

ANJOS-SILVA, E.J., CAMILLO, E. and GARÓFALO, C.A., 2006. Occurrence of Aglae caerulea (Hymenoptera: Apidae: Euglossini) in the Parque Nacional da Chapada dos Guimarães, Mato Grosso state, Brazil. Neotropical Entomology, vol. 35, no. 6, pp. 868-870. http://dx.doi.org/10.1590/S1519-566X2006000600024. PMid:17273723.

BRITO, C.M.S. and RÊGO, M.M.C., 2001. Community of male Euglossini bees (Hymenoptera: Apidae) in a secondary forest, Alcântara, MA, Brazil. Brazilian Journal of Biology $=$ Revista Brasileira de Biologia, vol. 61, no. 4, pp. 631-638. http://dx.doi. org/10.1590/S1519-69842001000400012. PMid:12071319.

CAMERON, S.A., 2004. Phylogeny and biology of neotropical orchid bees (Euglossini). Annual Review of Entomology, vol. 49, no. 1, pp. 377-404. http://dx.doi.org/10.1146/annurev. ento.49.072103.115855. PMid:14651469.

CAMPOS, L.A.O., SILVEIRA, F.A., OLIVEIRA, M.L., ABRANTES, C.V.M., MORATO, E.F. and MELO, G.A.R., 1989. Utilização de armadilhas para a captura de machos de Euglossini (Hymenoptera, Apoidea). Revista Brasileira de Zoologia, vol. 6, no. 4, pp. 621626. http://dx.doi.org/10.1590/S0101-81751989000400008.

CARVALHO, C.C., RÊGO, M.M.C. and MENDES, F.N., 2006. Dinâmica de populações de Euglossina (Hymenoptera, Apidae) em mata ciliar, Urbano Santos, Maranhão, Brasil. Iheringia: Série Zoologia, vol. 96, no. 2, pp. 249-256. http://dx.doi.org/10.1590/ S0073-47212006000200016.

CONCEIÇÃO, G.M. and RODRIGUES, M. S., 2010. Pteridófitas do Parque Estadual do Mirador, Maranhão, Brasil. Caderno de Geociência, vol. 7, pp. 47-53.

CONCEIÇÃO, G.M., RUGGIERI, A.C. and RODRIGUES, M.S., 2011. Malpighiaceae do cerrado do Parque Estadual do Mirador, Maranhão, Brasil. Scientia Plena, vol. 7, no. 2, pp. 1-6.

DRESSLER, R.L., 1982. Biology of the orchid bees (Euglossini). Annual Review of Ecology Evolution and Systematics, vol. 13, no. 1, pp. 373-394. http://dx.doi.org/10.1146/annurev. es.13.110182.002105.

HENTRICH, H., KAISER, R. and GOTTSBERGER, G., 2007. Floral scent collection at the perfume flowers of Anthurium rubrinervium (Araceae) by the kleptoparasitic orchid bee Aglae Caerulea (Euglossini). Ecotropica, vol. 13, pp. 149-155.

MENDES, F.N., RÊGO, M.M.C. and CARVALHO, C.C., 2008. Abelhas Euglossina (Hymenoptera, Apidae) coletadas em uma monocultura de eucalipto circundada por cerrado em Urbano Santos, Maranhão, Brasil. Iheringia: Série Zoologia, vol. 98, no. 3, pp. 285-290. http://dx.doi.org/10.1590/S0073-47212008000300001.

MORATO, E.F., 2001. Ocorrência de Aglae caerulea Lepeletier \& Serville (Hymenoptera, Apidae, Apini, Euglossina) no estado do Acre, Brasil. Revista Brasileira de Zoologia, vol. 18, no. 3, pp. 1031-1034. http://dx.doi.org/10.1590/S0101-81752001000300034.

MOURA, D.C. and SCHLINDWEIN, C., 2009. Mata Ciliar do Rio São Francisco como biocorredor para Euglossini (Hymenoptera, Apidae) de florestas tropicais úmidas. Neotropical Entomology, vol. 38, no. 2, pp. 281-284. http://dx.doi.org/10.1590/S1519566X2009000200018. PMid:19488520.

MOURE, J.S., 1964. A key to the parasitic Euglossinae bees and a new species of Exaerete from Mexico (Hymenoptera, Apoidea). Revista de Biologia Tropical, vol. 12, no. 1, pp. 15-18.

RAMÍREZ, S., DRESSLER, R.L. and OSPINA, M., 2002. Abejas euglosinas (Hymenoptera: Apidae) de la Región Neotropical: Listado de especies con notas sobre su biologia. Biota Colombiana, vol. 3 , no. 1 , pp. 7-118.

REBÊLO, J.M.M. and SILVA, F.S., 1999. Distribuição das abelhas Euglossini (Hymenoptera, Apidae) no Estado do Maranhão, Brasil. Anais da Sociedade Entomológica do Brasil, vol. 28, no. 3, pp. 389-401. http://dx.doi.org/10.1590/S0301-80591999000300003.

SILVA, D.P., AGUIAR, A.J.C., MELO, G.A.R., ANJOS-SILVA, E.J. and MARCO JUNIOR, P., 2013. Amazonian species within the Cerrado savanna: new records and potential distribution for Aglae caerulea (Apidae: Euglossini). Apidologie, vol. 44, no. 6, pp. 673-683. http://dx.doi.org/10.1007/s13592-013-0216-7.

SILVA, F.S. and REBÊLO, J.M.M., 2002. Population dynamics of Euglossinae bees (Hymenoptera, Apidae) in an early secondgrowth forest of Cajual island, in the State of Maranhão, Brazil. Brazilian Journal of Biology $=$ Revista Brasileira de Biologia, vol. 62, no. 1, pp. 15-23. http://dx.doi.org/10.1590/S151969842002000100003 . PMid:12185914.

SILVA, F.S., 2012. Orchid bee (Hymenoptera: Apidae) community from a gallery forest in the Brazilian Cerrado. Revista de Biologia Tropical, vol. 60, no. 2, pp. 625-633. http://dx.doi.org/10.15517/ rbt.v60i2.3949. PMid:23894934.

SILVA, O., RÊGO, M.M.C.,ALBUQUERQUE, P.M.C. and RAMOS, M.C., 2009. Abelhas Euglossina (Hymenoptera: Apidae) em área de restinga do nordeste do Maranhão. Neotropical Entomology, vol. 38, no. 2, pp. 186-196. http://dx.doi.org/10.1590/S1519566X2009000200004. PMid:19488506.

SILVEIRA, F.A., MELO, G.A.R. and ALMEIDA, E.A.B., 2002. Abelhas brasileiras: sistemática e identificação. Belo Horizonte: Edição do autor. 253 p.

WILLIAMS, N.H. and DODSON, C.H., 1972. Selective attraction of male euglossine bee to orchid floral fragrances and its importance in long distance pollen flow. Evolution; International Journal of Organic Evolution, vol. 26, no. 1, pp. 84-95. http://dx.doi. org/10.2307/2406985. 